\title{
Bioactivity of Khail-khail (Elaeagnus latifolia) Leaf Extract to Bacteria Staphylococcus saprophyticus and Salmonella enterica
}

\author{
Destria Roza $^{1}$, Ani Sutiani ${ }^{2}$, Rendi Meilano ${ }^{3}$ \\ \{destriaroza@unimed.ac.id\} \\ Chemistry Department, Faculty of Mathematics and Science State University of Medan ${ }^{1,2,3}$
}

\begin{abstract}
Khail-khail (Elaeagnus latifolia) is one of the plants endemic to Samosir Island in North Sumatra. Nowadays, further research was needed to explore bioactive compounds produced by these plants. This study aimed to assess the antibacterial activity of plant extract against Staphylococcus saprophyticus and Salmonella enterica. The methods of antibacterial activity test were Paper Discs and Microdilution. The Antibacterial activity results used paper disc method against Staphylococcus saprophyticus showed a weak inhibition and Resistant (R). Moreover, the MIC and KBM values with microdilution method were $1250 \mu \mathrm{g} / \mathrm{mL}$.
\end{abstract}

Keywords: Elaeagnus latifolia, Isolation, Identification, Secondary Metabolite, Staphylococcus saprophyticus, Salmonella enterica..

\section{Introduction}

Indonesia has the potential as source of bioactive compounds from many plants. It has more than 38,000 types of plants with 55\% are endemic plants (Sahromi, 2016). The use of these plants has been practiced and used in animals and humans albeit with a small amount. Basically, each of these plants contains substances or compounds that can provide a treatment effect or prevention of a particular disease.

Samosir District, North Sumatra province itself has approximately 48 potential plant species, namely timber producers (11 species), fruit producers (11 species), ornamental plants (22 species), traditional medicines (14 species) and herbs (3 species) (Sahromi, 2016). One of these plants is Elaeagnus latifolia which is often called "khail-khail". The fruit of many members of this genus is a very rich source of vitamins and minerals, especially vitamins A, C, and E (Seal, 2012), flavonoids and other bioactive compounds. Fruit from this plant genus is also a good source of essential fatty acids, which are commonly contained in the fruit. Several studies are being carried out to see the fruit's potential to stop or to reduce cancer growth (Oleaster, 2014).

Some types of bacteria can cause certain diseases. Some of these bacteria include Staphylococcus saprophyticus and Salmonella enterica. Sta-phylococcus saprophyticus is a bacterium that causes urinary tract infections. This bacterium is the second most common cause of urinary tract infection after Escherichia coli in women aged 17-27 years (Rupp, et al. 1992). Meanwhile, Salmonella enterica is one of the bacteria that causes salmonellosis (Swanson et. al., 2007). 
Several studies on the leaves of khail-khail plants have been carried out quite a lot. Phanjom, et. al., (2012) using extracts from these leaves to mediate the synthesis of silver nanoparticles, obtained stable silver nanoparticles with an average size of $30 \mathrm{~nm}-50 \mathrm{~nm}$. Arbiastutie, et al., (2016) in a study of several plants in Pangrango Gunung Gede National Park stated that leaf extracts from this plant have IC50 around 389.39 (moderate) to cervical cancer cells. Quattrocchi, (2012) in his book states that the leaves of this plant can be used to treat urinary tract infections.

Previous research conducted by Yanti, (2017) on the leaves of Elaeagnus latifolia plant extracted with ethanol solvent got results in the form of alkaloids in certain fractions and had good antioxidant activity. In addition, the extracted of the leaves, fruits, and seeds of this plant with methanol solventand tested its bioactivity against E. coli, S. dysentiae, and B. subtilis with ampicillin control got the results of antibacterial activity from the extract Marshillong's research (2017)

Due to the small number of plants Elaeagnus latifolia especially in Indonesia, it is very rare to find research on these plants, so the lack of information about the benefits found in the leaves of this plants. It is expected that with the development of research on Elaeagnus latifolia plants, it will support the cultivation and preservation of this type of medicinal plants in Indonesia. Therefore, researchers are interested in isolating and characterizing secondary metabolites using acetone solvents and testing for antibacterial properties against the bacteria Staphylococcus saprophyticus and Salmonella enterica. owned by plant leaves Elaeagnus latifolia to increase the usefulness of these plants

\section{Materials and methods}

This study was conducted at the Research Laboratory and Microbiology Laboratory, Department of Chemistry, Medan State University, Williem Iskandar Pasar V Street, Medan Estate, Deli Serdang, North Sumatra.

\subsection{Materials}

The materials used in this study is a plant leaf khail-khail (Elaeagnus latifolia), acetone, filter paper, $\mathrm{FeCl} 35 \%$ and $1 \%, 2 \mathrm{~N} \mathrm{HCl}$, distilled water, Dragendorff reagent, acetic anhydride, H2SO4, TLC plate, silica gel merck 60 GF254, silica gel Merck (230-400 mesh), n-hexane, ethyl acetate, and chloroform. For antibacterial test materials were used MuellerHintonAgar(MHA), Mueller-Hinton Broth (MHB), dimethyl sulfoxide (DMSO), chloroamphenicol, $0.9 \% \mathrm{NaCl}$, bacterial cultures of Staphylococcus saprophyticus and Salmonella enterica.

The instruments was used in this research is analytical balance, a set of glasses, TLC chamber, UV lamp (UVP UVGL-55), erlenmeyer flask, vacuum pump, Buchner funnel, column for chromatography, column for vacuum liquid chromatography (VLC), rotary evaporator Heidolph Base HeiVAP HL, incubator, autoclave TOMY ES-315, oven, Petridish, microplate, cotton bud, FT-IR ThermoFisher Scientific Spectrophotometer and 1H-NMR (Nuclear Magnetic Resonance) Spectro-photometer. 


\subsection{Methods}

The Methods used in this research included Extraction, Paper Disc Diffusion, Microdilution, VLC, TLC and GCC. The characterization of compound using FT-IR and 1HNMR

\subsubsection{Leaf extraction of khail-khail plants}

Extraction is done by maceration method. A total of $1.3 \mathrm{~kg}$ Elaeagnus latifolia leaves that have been mashed, dried, and macerated with acetone $3 \times 24$ hours. The macerated acetone extract was combined and filtered. The obtained filtrate was evaporated using a rotary evaporator at low pressure, resulting in acetone extract.

\subsubsection{Screening of phytochemical com-pounds secondary metabolites}

Analysis flavonoid group compound

The presence of flavonoid group compounds was done by adding two drops of $\mathrm{FeCl} 35 \%$ solution on five drops of sample on the drop plate. Its happening greenish color changes to black or blue indicate the presence of flavonoids.

Analyses alkaloids group compounds test

The presence of alkaloid group compounds was done by adding 0.5 grams of a sample with $1 \mathrm{ml}$ of $2 \mathrm{~N} \mathrm{HCl}$ and added with $9 \mathrm{ml}$ of distilled water then added with 5 drops of Dragendorff reagent. The presence of red brick deposits indicated the presence of alkaloids.

Analysis Steroid and Terpenoids Group Compound

The presence of steroids and terpenoids compounds made by adding 0.5 gram of extract with 10 drops of acetic anhydride plus 2 drops concentrated sulfuric acid. The mixture were shaken and left a few minutes. The incidence of red and purple color indicates positive triterpenoids. In additon, the emergence of green and blue colors indicate positive steroids.

Tanin group compound test

The test of the presence of tannin class compounds was carried out by adding 0.5 grams of extract with $10 \mathrm{~mL}$ of distilled water and added with 3 drops of $\mathrm{FeCl} 31 \%$, the appearance of a blackish green color shows positive tannin.

\subsubsection{Analysis antibacterial activity}

Media and sterilization

Bacterial storage media was made using Mueller-Hinton media. MHA powder was weighed 38 grams and mixed with 1 liter of distilled water, while for 21 grams of MHB dissolved in 1 liter of distilled water. The media and all the devices that will be used for analysis are autoclaved $121^{\circ} \mathrm{C}$ for 15 minutes (Pelczar, 2005).

\section{Bacterial suspension}

The bacteria that will be used first were cultured before being used for test. The bacterias that have been sterile and smeared on MHA media, put into the incubator to be incubated at $37^{\circ} \mathrm{C}$ for 24 hours. After that the bacteria are suspended into $0.9 \% \mathrm{NaCl}$ to the $\mathrm{McFarland} 0.5$ 
standard $(0.5 \mathrm{~mL} \mathrm{BaCl} 20.048 \mathrm{~mol} / \mathrm{L}$ in $99.5 \mathrm{~mL} \mathrm{H} 2 \mathrm{SO} 40.18 \mathrm{~mol} / \mathrm{L})$. The suspension of bacteria into $0.9 \% \mathrm{NaCl}$ is the same as bacterial dilution of $10-6 \mathrm{CFU} / \mathrm{mL}$ (McFarland Standard 0.5).

Paper disc diffusion method test

In this test, the concentration of test extracts used were $100,50,25$ and $12.5 \mu \mathrm{g} / \mu \mathrm{L}$ with DMSO solvents (Natheer, et al. 2012). The $100 \mu \mathrm{L} / \mu \mathrm{L}$ test extract was prepared by weighing $0.01 \mathrm{~g}$ extract and dissolved in $1 \mathrm{~mL}$ DMSO. Concentrations of 50, 25 and $12.5 \mu \mathrm{g} / \mu \mathrm{l}$ are made by performing serial dilution extracts with DMSO. Bacterial suspension was taken with a cotton bud and smeared on MHA media which has been prepared in advance. Each Petri dish was made with a diagram of 6 parts and each section was placed in a disc paper that has been dripped with $20 \mu \mathrm{g}$ of test extract.

The positive control used was $30 \mu \mathrm{g}$ of chloramphenicol antibiotic disc while the DMSO solvent used for negative control (Natheer et al. 2012). Positive control disc paper, negative control, and discs that have been dripped with extract solution, placed on each part and then incubated at $37^{\circ} \mathrm{C}$ for 24 hours (Nufailah, 2008). The clear area around the disc shows no bacterial growth which was measured using a caliper run. The inhibition zone measurement results are classified based on Tabel 1.

Table 1.Classification of Antibacterial Activities (Greenwood, 1995).

\begin{tabular}{|c|c|}
\hline $\begin{array}{l}\text { Diameters of Inhibition } \\
\text { Zone }(\mathrm{mm})\end{array}$ & Antibacterial Activity \\
\hline$\leq 10$ & No Activity \\
\hline$\overline{10}-15$ & Weak \\
\hline $15-20$ & Medium \\
\hline$\geq 20$ & Strong \\
\hline
\end{tabular}

Microdilution method test (marliyana, et al. 2017)

Before the antibacterial test, a test solution (sample) was prepared using a DMSO solvent with a concentration of $1000 \mu \mathrm{g} / \mathrm{mL}$. MHB liquid media that has been suspended with $100 \mu \mathrm{L}$ of bacteria is inserted into each microplate hole. In the first hole, $100 \mu \mathrm{L}$ of the test solution is added. The solution concentration series was carried out by transferring $100 \mu \mathrm{L}$ of solution from the first hole to the second hole, from the second hole $100 \mu \mathrm{L}$ was taken and put into the third hole, the same was done to the tenth hole.

The next two holes were used for two control solutions. For the first control the hole was filled with $100 \mu \mathrm{L}$ of a liquid medium and $100 \mu \mathrm{L}$ of bacterial suspension (growth control), while for the control of the two holes only filled with $200 \mu \mathrm{L}$ of liquid medium (sterility control). The microplate is then incubated at $37^{\circ} \mathrm{C}$ for 24 hours. The antibiotic control used in this study was chloramphenicol. The determination of MIC was carried out based on observations on the concentration that began to appear bacterial growth and MBC was determined by placing $5 \mu \mathrm{L}$ of samples that were not overgrown with bacteria in the agar medium, then incubated again for 24 hours. The determination of MBC was based on bacteria that did not grow in the media. 


\subsubsection{Isolation of components of khail-khail plant leaf extract}

\section{Separation with VLC and TLC}

The acetone extract was fractionated using liquid vacuum chromatography with a column diameter of $10 \mathrm{~cm}$ and adsorbent height $5 \mathrm{~cm}$. Fractionation was carried out using $60 \mathrm{GF} 254$ silica gel Merck as a stationary phase and mobile phase in the form of eluent n-hexane, nhexane, ethyl acetate, ethyl acetate (variation based on polarity level) with various eluent comparisons. The resulting fraction is then monitored by TLC with the n-hexane mobile phase: ethylacetate for eluent test. The same Rf values will be grouped into several combined fractions, which are then tested for phytochemicals again.

Separation by gravity column chromatography

The combined fraction with the same pattern of Rf results from VLC, fractionated further by GCC with a silica gel Merck 60 and motion fraction n-hexane:ethyl acetate. The fractions obtained from the eluent were monitored by TLC with the n-hexane: ethyl acetate mobile phase with a comparison obtained from the previous TLC. The same Rf value was combined and then one of the fractions was selected based on the incorporation of the $\mathrm{Rf}$ value in the TLC with the three-eluent test namely n-hexane: ethyl acetate $(1: 1)$, n-hexane: chloroform $(1: 1)$ and ethyl acetate: chloroform (1:1) samp a i indicates a single spot.

\subsubsection{Characterization of component compounds of khail-khail plant leaf extract}

Component structure characterization is carried out including analysis by using FT-IR spectroscopy and 1H-NMR spectroscopy. 1H-NMR is useful for determining parts of hydrogen and carbon from a compound. The FT-IR analysis is useful for knowing the functional groups of the isolated compounds by observing the wave numbers produced

\section{Result and discussions}

\subsection{Phytochemical screening test results of secondary metabolites}

Extracts obtained from the maceration process were then tested by phytochemical screening for qualitative analysis of secondary metabolites contained in extracts obtained. The results of phytochemical screening tests for extracts are shown in Table 2.

Table 2 : Phytochemical screening test result of acetone extract of plant leaves of elaeagnus latifolia.

\begin{tabular}{ll}
\hline Group & Test Results \\
Flavonoid & + \\
Saponin & + \\
Alkaloid & + \\
Terpenoid & - \\
Steroid & + \\
Tanin & - \\
\hline
\end{tabular}




\subsection{Antibacterial test results}

\subsubsection{Antibacterial test results for paper disc method}

Based on the average diameter value of the inhibition zone shown in Table 3 . The inhibitory zone value of the extract tested on S. saprophyticus bacteria which was a grampositive bacteria showed better inhibitory activity compared to S.enterica bacteria.

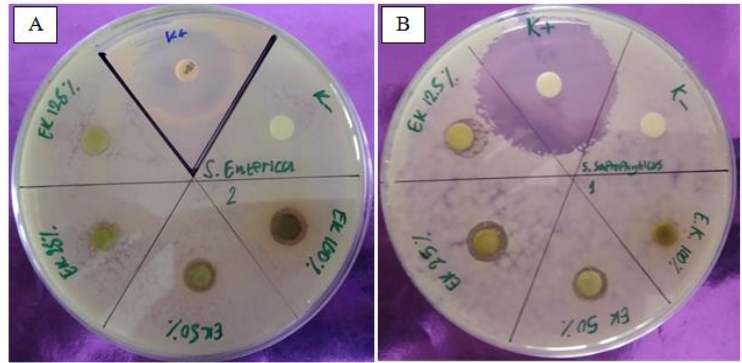

Fig. 1. Results of extracted paper discs test on bacteria A) S.enterica and B) S.saprophyticus

Table 3. Diameter of inhibitory zone results in antibacterial test with paper disc method.

\begin{tabular}{lll}
\hline $\begin{array}{l}\text { Concentration } \\
\text { Sample }(\mu \mathrm{g} / \mu \mathrm{L})\end{array}$ & of & $\begin{array}{l}\text { Zone of Inhibition }(\mathrm{mm}) \\
\text { S. enterica }\end{array}$ \\
Control $(+)$ & $27.35 \pm 2.62$ & $35.75 \pm 0.21$ \\
Control (-) & 0 & 0 \\
100 & $9.05 \pm 1.06$ & $7.40 \pm 0.14$ \\
50 & $8.15 \pm 0.35$ & $9.15 \pm 0.07$ \\
25 & $7.75 \pm 0.78$ & $10.55 \pm 0.49$ \\
12.5 & $8.25 \pm 0.07$ & $10.60 \pm 0.42$ \\
\hline
\end{tabular}

The inhibition zone value of S. saprophyticus was classified as weak for extract concentrations of $25 \mu \mathrm{g} / \mu \mathrm{L}$ and $12.5 \mu \mathrm{g} / \mu \mathrm{L}(10-15 \mathrm{~mm})$ based on Greenwood classification (1995) and no inhibitory activity $(<10 \mathrm{~mm})$ in S. enterica. Meanwhile, according to the standards set by CLSI M100 (2017), the inhibitory activity of the extracts used in this study was in the R or Resistant $(\leq 12 \mathrm{~mm})$ category .

Based on the results, more Gram -negative bacteria can withstand acetone extract Khailkhail plant leaves compared to gram-positive bacteria. The compounds in the extract will bind to peptidoglycan so that it can damage the cell wall and the growth of gram-positive bacteria can be inhibited when the extract works on it. The compounds extracted are more polaras well as peptidoglycan which consisted of polar proteins and carbohydrates because acetone is more likely to be polar. Where as in Gram negative bacteria, the compounds in the extract cannot directly bind with peptidoglycan but must damage the outer membrane first. Its cause of 
Gram-negative bacteria is more difficult to inhibit than gram-positive bacteria (Mulyadi, et al. 2017).

\subsubsection{Antibacterial test results for micro-dilution method}
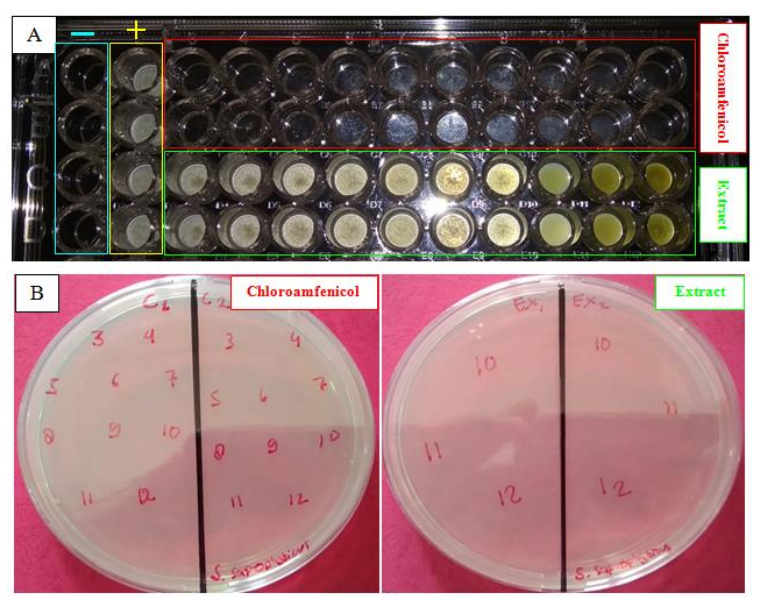

Fig. 2.results of testing the microdilution method antibacterial activity for determination of A) MIC and B) MBC.

Table 4. The value of MIC and MBC test results with the microdilution method.

\begin{tabular}{lllll}
\hline \multicolumn{3}{l}{ Bacterial Growth } & & \\
Concentration of Extract $(\mu \mathrm{g} / \mathrm{mL})$ & MIC & MBC & \\
& C & Ex & C & Ex \\
9.73 & - & + & - & + \\
19.45 & - & + & - & + \\
39.06 & - & + & - & + \\
78.13 & - & + & - & + \\
156.25 & - & + & - & + \\
312.50 & - & + & - & + \\
625.00 & - & + & - & + \\
1250.00 & - & - & - & - \\
2500.00 & - & - & - & - \\
5000.00 & - & - & - & - \\
\hline
\end{tabular}


Test results in Table 4. showed that the MIC values and MBC extracts of khail-khail plant leaves were the same value. Based on the standards set in CLSI M100 (2017), the MIC values in the extracts tested in this study were in the $\mathrm{R}$ or Resistant category $(\geq 32 \mu \mathrm{g} / \mathrm{mL})$. In addition, the MIC and MBC extract values also good compared to the MIC and MBC results of plants with the same genus ( Elaeagnus ) reported by Dehghan, et al (2014) on plants Elaeagnus Angustifolia and Różalska, et al (2018) in the Elaeagnus Rhamnoides plant

\subsection{Isolation of extract component components}

Isolation of component compounds contained in the extract of khail-khail plant leaves was carried out by two methods, namely liquid vacuum chromatography and gravity column chroma-tography. After being separated, the results of the isolates were tested by using TLC. The TLC test results were shown in Figures 3 and 4.

\subsection{Characterization of extract compound with FT-IR and1H-NMR}

The isolates fraction tested showed that the isolates had several types of functional groups, namely amines, alkanes, aldehydes, alkenes, alkyl halides, and aromatics based on the IR spectrum data,

\subsection{Phytochemical}

Extracts obtained from the maceration process were then tested by phytochemical screening for qualitative analysis of secondary metabolites contained in extracts obtained. The results of phytochemical screening tests for extracts are shown in Table 2.

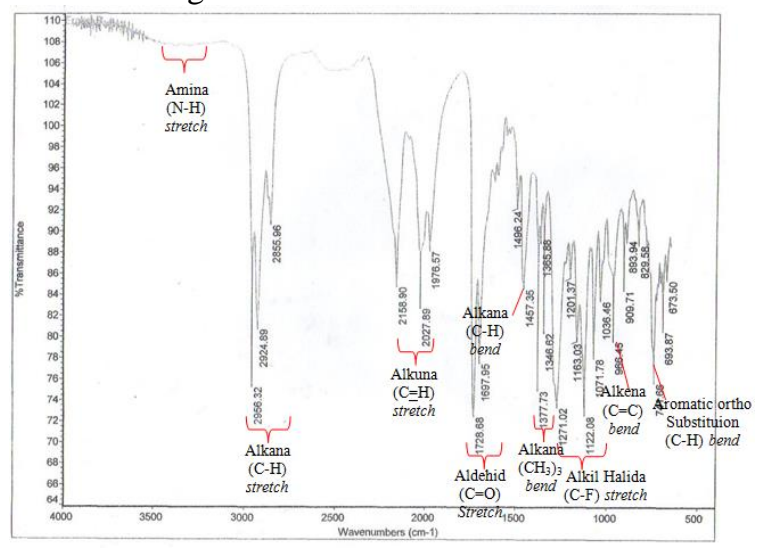

Fig. 5. Results of isolate faction sample sample FT-IR spectrograms. 


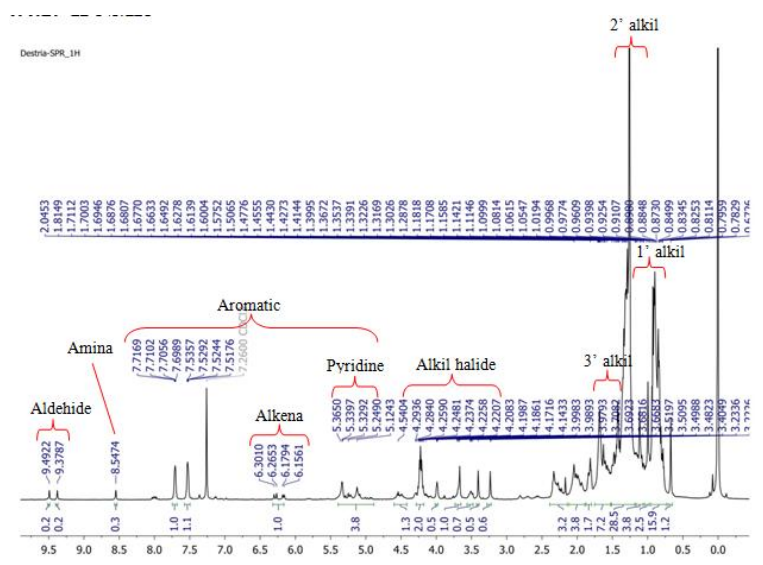

Fig. 6. Results of ${ }^{1} \mathrm{H}-\mathrm{NMR}$ spectra sample isolate fraction.

The results of the analysis with 1H-NMR spectroscopy isolated compounds which with CDCL3 solvent there were 2 signal peaks at $\delta 8.5 \mathrm{ppm}$ indicated $1 \mathrm{H}$ in the aldehyde group (Sudjadi, 1983),singlet signal $\delta 9.5 \mathrm{ppm}$ indicating $1 \mathrm{H}$ in the amine group (Pavia et al. 2008). $\delta 5.5-5 \mathrm{ppm}$ it indicates that there is $1 \mathrm{H}$ in the pyridine group.

The structure elucidation of the compound cannot be continued with structural reading due to the use of 13C-NMR spectroscopy which was not carried out in this study. The isolation of these compounds produced limited yield so it was not enough to testwith13CNMR spectroscopy so that the structure of the compound was unpredictable. However,it was found that isolated compounds were alkaloid based on the results of FT-IR and 1H-NMR. This is due to the presence of an amine ( $\mathrm{NH} 2)$ and aromatic groups in the form of pyridine which is known in the 1H-NMR spectrum.

The presence of alkaloid group compounds in the leaves of Elaeagnus latifolia plants was also supported by the study of Minhas, et al (2018) who succeeded in finding alkaloid group compounds namely 2-(1-hydroxy-2methylpropyl)-3-(2-hydroxyethyl) -1-methyl -1 H-indole4,7-diol which is one of the indole alkaloids. In addition, Aniszewski (2007) also states that the genus Elaeagnus contains at least alkaloids which are derivatives of L-tryptophan namely Elaeagnine derived from amino acids.

\section{Conclusions}

The isolation and identification of secondary metabolites from Elaeagnus latifolia leaves is an alkaloid group compound based on the results of analysis using spectroscopy FT- IR and 1H-NMR. Antibacterial activity test for Khail-khail plant leaf extract against S. enterica and S. saprophyticus bacteria showed good inhibition on S. saprophyticus bacteria with MIC and MBC values of $1250 \mu \mathrm{g} / \mathrm{ml}$, respectively. 


\section{References}

[1]Arbiastutie, Y., Marsono, D., Hartati, M.S., dan Purwanto, R., 2016.The Potential of Understorey Plants from Gunung Gede Pangrango National Park (West Java, Indonesia) as cervixs anticancer agents, Biodiversitas

[2]CLSI, 2017. Performance Standards for Antimicrobial Suspecbility Testing: M100, 27th Ed. Clinical and Laboratory Standards Institute, USA.

[3]Dehghan, M.H., Soltani, J., Kalantar, E., Farnad, M., Kamalinejad, M., Khodaii, Z., Hatami, S., Na-tanzi, M.M., 2014. Characterization of an Antimicrobial Extract from Elaeagnus angustifolia. Int. J. Enteric. Pathog.

[3]Greenwood, (1995), Antibiotics, Susceptibility (Sensitivity) Test Antimicrobial AndChemoterapy. Mc. Graw Hill Company, USA.

[4]Marliyana, S.D., Syah, Y.M., dan Mujahidin, D., 2017. Aktivitas Antibakteri Secara In Vitro Terhadap Bakteri Isolat Klinis Turunan Calkon dari Rimpang Kaempferia pandurata, Jurnal Penelitian Kimia.

[5]Marshillong, K.L., 2017. Qualitative Phytochemical Study of Bioactive Compounds from Natural Source (Elaeagnus Latifolia and Flemingia Vestita) and Screening of Antimicrobial and Antifungal Activity, Thesis, Departemen of Life Science, Assam Don Bosco University, New Delhi.

[6]Mulyadi, M., Wuryanti dan Sarjono, P.R., 2017. Konsentrasi Hambat Minimum (KHM) Kadar Sampel Alang-alang (Imperata cylindrica) dalam Etanol Melalui Metode Difusi Cakram. Jurnal Kimia Sains dan Aplikasi.

[7]Natheer, S.E., Sekar, C., Amutharaj, P., Rahman, M.A., dan Khan, K.K., 2012. Evaluation of Antibacterial Activity of Morinda citrifolia, Vitex trifolia and Chromolaena odorata, African journal of Pharmacy andPharmacology.

[8]Nufailah, D., 2008. Uji Aktivitas Antibakteri Produk Reduksi Asam Palmitat Dalam Sistem NaBH4/ BF3.Et2O Terhadap Escherichia coli Dan Staphylococcus aureus, Skripsi, FMIPA, Universitas Diponegoro, Yogyakarta.

[8]Oleaster, B., 2014. Useful tropical plants Elaeagnus latifolia. http://tropical. theferns.info/viewtropical.php?id=Elaeagnus+latifolia (Diakses pada 18 Januari 2018).

[9]Pavia, D.L., Lampman, G.M., Kriz, G.S., dan Vyvyan, J.R., 2009. Introduction to Spectroscopy, Brooks/Cole, Washington.

[10]Pelczar, M.J., 2005. Dasar-dasar Mikrobiologi, UI Press, Jakarta.

[11]Phanjom, P., Sultana, A., Sarma, H., Ramchiary, J., Goswami, K., dan Baishya, P., 2012. Plant-Mediated Synthesis of Silver Nanoparticles Using Elaeagnus latifolia Leaf Extract, Digest Jounal of Nanomaterials and Biostuctures.

[12]Quattrocchi, U., 2012.CRC World Dictionary of Medicinal and Poisonous Plants, CRC Press, UK.

[13]Rozalska, B., Sadowska, B., Zuchowski, J., Szakiel, M.W., Budzynska, A., Wojcik, U. dan Stochmal, A., 2018. Phenolic and Nonpolar Fractions of Elaeagnus rhamnoides (L.) A. Nelson Extracts as Virulence Modulators-In Vitro Study on Bacteria, Fungi, and Epithelial Cells. Molecules.

[14]Sahromi, S.H., (2016), Kebun Raya Samosir: Studi Tentang Kekayaan Flora dan Potensinya, Pros. Sem. Nas. Masy. Biodiv. Indon.

[15]Seal, T., 2012. Evaluation of nutritional potential of wild edible plants, traditionaly used by the tribal people of Meghalaya State in India, American Journal of Plant Nutrition and Fertilization Technology. 
[16]Silverstein, R.M., Webster, F.X., dan Kiemle, D.J., 2005. Spectrometric Identification of Organic Compounds, Ed ke-7, Jhon Wiley \& Sons, USA.

[17]Sudjadi, 1983. Penentuan Struktur Senyawa Organik, Ghalia Indonesia, Yogyakarta.

[18]Swanson, S.J., Snider, C., Braden, C.R., Boxrud, D.,2007. Multidrug-Resistant Salmonella enterica Serotype Typhimurium Associated with Pet Rodents, New England Journal of Medicine. 